Kusari Nertila, Sukova-Stojmanovska Daniela, Elezi Abdulla. Correlation of body composition with depression level. Journal of Education, Health and Sport. 2020;10(11):104-113. eISSN 2391-8306. DOI http://dx.doi.org/10.12775/JEHS.2020.10.11.011

https://apcz.umk.pl/czasopisma/index.php/JEHS/article/view/JEHS.2020.10.11.011

https://zenodo.org/record/4279704

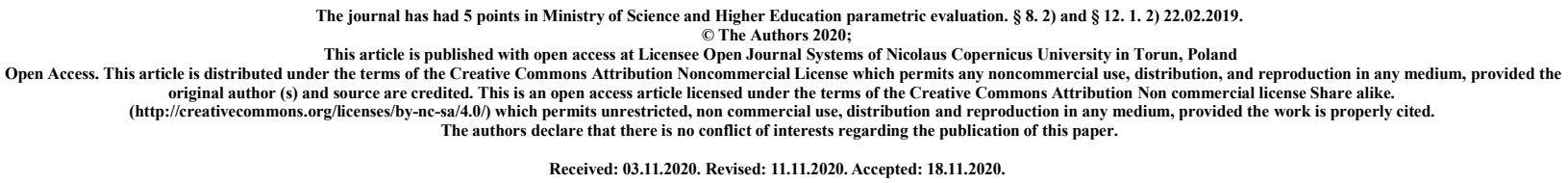

\title{
CORRELATION OF BODY COMPOSITION WITH DEPRESSION LEVEL
}

\author{
Nertila Kusari \\ "St. Cyril and Methodius" \\ Faculty of Physical Education, Sport and Health \\ North Macedonia
}

Daniela Sukova-Stojmanovska

"St. Cyril and Methodius"

Faculty of Physical Education, Sport and Health

North Macedonia

Principal contact for editorial correspondence. E-mail: danisukova@yahoo.com

\author{
Abdulla Elezi \\ University of Prishtina "Hasan Prishtina" \\ Faculty of physical education and sport \\ Kosovo
}




\begin{abstract}
Background: The purpose of this paper is to determine the impact of body development and composition on the depression level, and to determine which of the morphological and body composition parameters have higher impact on the manifestation of depression in women aged 19 to 30 years.

Methods: The study was conducted on the sample of 50 voluntarily selected test subjects. From 83 women presented at the fitness center "Fitnes Center Mall" in the city of Gjakova for the purposes of this study are voluntarily involved 50 women aged 19 to 30 years with an average age of 23.2 years. For the purpose of this paper were applied 11 body composition variables and one test for measuring depression levels.

Results: The obtained results show that the multiple correlation coefficient between the predictor and the criterion system is quite high $\mathrm{R}=0.962$. This relation shows that the common variability between the two systems is $93 \%(\mathrm{R}$ Square $=0.926)$. Predictive variables that has the influence in the manifestation of depression level are: Height of the body body (HEIG) $t=2.784 ; p<0.008$, Body weight (WEIG) $\mathrm{t}=-2.194 ; \mathrm{p}<0.034$, and Body mass index (BMI) $\mathrm{t}=2.908 ; \mathrm{p}<0.006$. Conclusions: The research results show that Height of the body, Body weight, and Body mass index affect in the rate of depression level. Research shows that although mental and physical health are two separate concepts, yet they are still in a strong relationship, physical condition affects in mental state.
\end{abstract}

Key words: Body composition, females, the level of depression, regression analysis.

\title{
INTRODUCTION
}

Ways of modern lifestyles, social status, reduced physical activity, malnutrition and genetic factors all contribute to increasing the incidence of overweight in the world. Of particular concern is the tendency to increase obesity among the younger population. Statistics show that overweight in women is more pronounced and greater than in men. Obesity is widespread in the world and it is thought that the $21^{\text {st }}$ century marked the time when overweight took epidemic features.

Living conditions, social status, physical activity and genetic predisposition are just some of the factors that influence human body composition.(Lohman, 1992). On the basis of the body composition of an individual, one can gain an impression of a lifestyle that incorporates both 
good and bad habits and is reflected in the body structure giving it a unique personal characteristic. (Maksimovic, 2008). Determining of body composition is a common method not only within medical disciplines but also in the sports sciences, then in anthropology and pedagogy. Therefore, there is growing interest in new and modern methods in determining body composition. The focus is usually on determining the fat component in order to analyzed the health status and assess the existence of a potential health risk. (Ostojic, 2005).

Women after late adolescence begin to place great importance on appearance and gain confidence in themselves. Understanding yourself means notion of you, self-image, etc. Selfconcept is a set of thoughts and attitudes that an individual has for him. (Alić, 2015. according to Fox, 1997). According to Alić dhe Fox (Alić, 2015; Fox, 1997) is one "mental image that an individual has for himsel", and like this self-understanding is like the mental one, mirror that reflects how a person sees himself, not only his body features, but also emotional state, talent, what he likes and dislikes, his values and roles. Many authors define self-understanding as a descriptive aspect of themselves. One-dimensional observation of self-perception defines it as an indivisible construct, referring to the general positive or negative attitude an individual has about himself (Alić, 2015. according to Marsh, 1985). Outward appearance, created self-esteem are two factors that depend on their appearance in society. Dissatisfaction in outward appearance and self-esteem leads to different modalities of behavior in society. From these dissatisfactions for themselves, often individual, and especially women fall in depression.

Depression is a major health problem in the world today. Although it has been observed that this condition affects both men and women with increasing frequency as they get older, the incidence of depression in women is approximately twice as high as in men.(American Psychiatric Association, 2014; Wolk и Weissman, 1995). This study made a research of the relationship between depressive symptoms and rates of physical activity in women with very high level of depression. Models of physical activity show that, at all ages in life, men have the tendency to be much more active than women. And, although levels of physical activity decrease as people gets old, regardless of their gender, older women remain less involved in physical activity than their male counterparts. Reduced physical activity has shown to increased depressive symptoms. (Lampinen, и сор., 2000), whereas an increase of depressive symptoms can lead to a decrease in the desire to engage in physical activity.(American Psychiat Association, 2014).

Depression has a major impact on various areas of individual functioning, as well as its overall health. Physical exercise is increasingly recognized as an effective intervention to improve these results. Therefore, the efforts of different authors are focused in finding different forms and toold in the management of depression. Like many studies, the study of authors (Blumenthalet et al., 1999) emphasize that physical activity has been identified as a potential management tool for mild to moderate depression. Increasing numbers of older people suffer from depression or depressive symptoms, and while it often goes untreated, the recommended and commonly used treatments have been medications and psychotherapy. However, medications, similar to psychotherapy, are an expensive way to manage the disease of depression. (Blumenthal и cop., 1999). Moreover, medications are often not taken continuously and have many potential side effects. Therefore, it is imaginable that physical exercise and various physical activities can serve as an effective tool and preventive method for depressive symptoms in adults.

Physical exercise is less costly, has essentially no side effects, and is an effective tool in improving good mood. In the last ten years, many surveys on this topic have tried to determine what is more effective in treating depression. It is thought that more aerobic activity is needed during the week with more intense exercises to improve spiritual condition. The antidepressant 
effect occurs very quicly, it would be said immediately after the first few days of training. However, the true effect is only achieved after 4 to 9 weeks. It is recommended the so-called aerobic exercises like jogging, swimming, cycling, walking and something similar. Compared to relaxing exercises, sports activities in depression are reported to be even better. (Martinsen, 1994). Physical activity is an important factor in a woman's quality of life, which is particularly reflected in: (a) improving health; (b) as a means of relaxation, recovery and recreation; and (c) tool that has an impact on increasing work capacity (Anastasovski, 2003).

In this way, the concept of active and healthy aging is seen through the context of an appropriate lifestyle, which implies a wide range of physical activities, as well as social, psychological, educational, aesthetic and other factors. (World Health Organization, 2006).

Also, should be considered proper eating habits, proper health care, family, stress management, etc. Physical exercise, in this context, represents a desirable model of human functioning. (World health Organization, 2006). The most significant positive effects of physical activity and physical exercise are viewed in human psychophysical equilibrium, and its role in socialization and in relation to the natural environment are classified as important and deserving of the overall human condition and therefore also for health. Dealing with physical activity is determined by socio-economic circumstances, acquired habits and the needs of the population, but also by educational, cultural, religious and other factors. Physical activity is a cultural way of relaxation, thus consciously achieving a beneficial effect on health. (Sabic, 2018). This research is a continuation of many studies of this nature and aims to establish the impact of morphological development and body components on the depression level.

\section{METHOD}

The study was conducted on the sample of 50 voluntarily selexted test subjects. From 83 women presented at the fitness center "Fitnes Centër Mall" in the city of Gjakova for the purposes of this study, are voluntarily involved 50 women aged from 19 to 30 years with an average age of 23.2 years. Respondents were treated in accordance with the Declaration of Helsink. For the purposes of this study were applied 11 body composition variables, and one test for measuring depression level. Body composition was measured by using the scale TANITA BC-601, bioelectriuc resistance method, which has become a very common method in maqny researches. (Sudarov dhe Fratric, 2010). Before measuring body components in the electronic scale, data are given for: body height, calendar age and gender. The parameters of Body Composition applied in this research are: Height of the body (HEIG), Body weight (WEIG), Bone mineral mass (BOMA, Total Body Water (TBWA) Daily Calorie Intake (DCI), Visceral fat (VIFA), Body mass index (BMI), Metabolic age (MEAG). Muscle mass MMAS, Body fat $\%$ (BOFA) and calendar age (AGE). The measurements were made at the fitness center "Fitnes Center Mall" in the city of Gjakova. Characteristics of individual items from A.T. Back: Sadness, Pessimism, Failure, Loss of Satisfaction, Guilt, Punishment, Dissatisfaction with Himself, Self-criticism, Suicide, Crying, Agitacija, Disinterest, Indecision, Worthlessness, Anergy, Sleeplessness, Irritability, Appetite, Concentration, Fatigue, Losing libido. The data was processed using the statistical package SPSS for Windows Version 22.0. These basic statistical and distribution parameters are applied, Minimum, Maximum, Mean, Std. Deviation, Skewness, Kurtosis. Regression analysis was used to analyze the correlation between predictor (independent, body composition and biochemical blood parameters) and criterion (dependent, level of depression). 


\section{RESULTS}

Within descriptive analysis are calculated basic statistical and distribution parameters as well as the asymmetry test (Skewness) and Kurtosis - is a measure of the "tailedness" of the probability distribution of a real-valued random variable, determined in body composition variables, and in the test that determines the level of depression. In table 1 are presented basic statistical indicators of body composition variables, biochemical blood parameters and a test that determines the level of depression. According to the asymmetry test (Skewness) only one body composition variable is obtained. Body weight (WEIG), which has a pronounced asymmetry (1.42) and Muscle mass (MMAS), which has a pronounced asymmetry (1.46). Normal asymmetry was obtained in all body composition variables, and depression level test, because the normal asymmetry of the distribution of results is treated when the Skewness values in the applied variables are in the interval between +/- 1.00 (Malacko et al., 1997).

Table 1. Basic statistical indicators of body composition variables and a test that determines the depression level.

\begin{tabular}{|l|c|r|r|r|r|r|r|}
\hline & $\mathrm{N}$ & Minimum & Maximum & Mean & Std. Dev & Skewness & Kurtosis \\
\hline HEIG & 50 & 154.00 & 179.90 & 165.31 & 5.99806 & -.09 & -.36 \\
\hline WEIG & 50 & 53.00 & 104.00 & 69.15 & 10.45 & 1.42 & 2.30 \\
\hline BOFA & 50 & 29.50 & 44.80 & 36.81 & 3.31 & -.19 & -.25 \\
\hline MMAS & 50 & 40.10 & 53.70 & 43.58 & 3.31 & 1.46 & 1.76 \\
\hline BOMA & 50 & 1.80 & 2.90 & 2.30 & .23 & .64 & .72 \\
\hline BMI & 50 & 18.17 & 34.35 & 25.29 & 3.36 & .67 & .55 \\
\hline DCI & 50 & 1813.00 & 2504.00 & 2171.34 & 157.65 & .15 & .00 \\
\hline MEAG & 50 & 26.00 & 43.00 & 35.74 & 4.08 & -.24 & -.34 \\
\hline TBWA & 50 & 41.90 & 57.80 & 48.30 & 3.68 & .47 & .28 \\
\hline VIFA & 50 & 1.00 & 8.00 & 3.96 & 1.59 & .64 & .26 \\
\hline AGE & 50 & 19.00 & 29.00 & 23.22 & 2.51 & .54 & -.51 \\
\hline DEPRES & 50 & 3.00 & 36.00 & 13.28 & 7.58 & .99 & .66 \\
\hline
\end{tabular}

The positive (epicurtic) value of the asymmetry teste (Skewness) indicated that the distribution of results skews to the rights, that is, the higher the number of results obtained below the value of the arithmetic average. Positive asymmetry was obtained in 9 body composition variables. The negative (hipocurtic) value of the asymmetry test (Skewness) indicates that the distribution of results skews to the left, that is, the greater the number of results obtained below the value of the arithmetic average. Negative asymmetry was obtained in 3 body composition variables.

By analyzing the asymmetry test values, that is, by analyzing the normality parameters of the distribution of results, it is seen that the values of the asymmetry test (Skewness) for most of variables are zero, except for variable (Body weight-WEIG), and this shows us about the normal distribution of the obtained results. Body composition variables, and depression level test that have a curtosis value of in interval 3,00, are treated as having normal flattening (Malacko et al., 1997). We can say that the values of symmetry (Skew.) and flatness (Kurt.) the distribution of 
results for the entire sample included in the research is within the normal distribution, (except for two variables), so that we can safely proceed with further statistical refinement and analysis of this area of research. With regression analysis is vertified the level of connectivity between the independent variables group, Body and biochemical blood composition with dependent variable (criterion) - level of depression (DEPRES). Connectivity of the whole system of independent variables, Height of the body (HEIG), Body weight (WEIG), Bone mineral mass (BOMA, Total Body Water (TBWA) Daily Calorie Intake (DCI), Visceral fat (VIFA), Body mass index (BMI), Metabolic age (MEAG). Muscle mass MMAS, Body fat \% (BOFA) and calendar age (AGE), and criterion dependent variable, degree of depression (DEPRES) is verified by multiple correlation. The multiple correlation coefficient between these two systems is quite high $\mathrm{R}=$ 0.962 . This connectivity shows that the common variability between the predictor variables system and the criterion variable is $93 \%(\mathrm{R}$ Square $=0.926)$.

Distribution (F) is obtained as the distribution of the two variants, and in these cases it is sometimes necessary to assign the two degrees of freedom. The first degree of freedom equals the number of predictor variables $(\mathrm{df}=\mathrm{n})$ respectively $(\mathrm{df}=11)$ whereas the second is performed so that the number of subjects (50) reduced to the number of predictor variables minus $1 \mathrm{~d} d \mathrm{df}=$ $\mathrm{N}-\mathrm{n}-1)$. We can emphasize that the test (F-test) is always more valuable if the multiple correlation is greater, in this case of this research is significant $(\mathrm{Sig}=0.000)$, because the value of F-test is $F=43.485$. In this research since multiple statistically significant correlation was obtained ( $\mathrm{R}=0.962)$ it is necessary to search for the coefficient in the column (Beta) as well as the value of (t-test) that indicate the influence of each predictor (independent) variable in the dependent criterion variable. (Table 2). 
Table 2. Connectivity of predictor variables (Body composition) with criterion variable (depression level)

\begin{tabular}{|l|r|r|r|r|}
\hline Model & \multicolumn{1}{c}{ R } & R Square & Adjusted R Square & Std. Error of the Estimate \\
\hline 1 & $.962 \mathrm{a}$ & .926 & .905 & 2.33454 \\
\hline
\end{tabular}

\begin{tabular}{|l|l|r|r|r|c|c|}
\hline \multicolumn{2}{|l|}{ Model } & Sum of Squares & df & Mean Square & F & \multicolumn{1}{l|}{ Sig. } \\
\hline \multirow{3}{*}{1} & Regression & 2606.978 & 11 & 236.998 & 43.485 & $.000 \mathrm{a}$ \\
\cline { 2 - 8 } & Residual & 207.102 & 38 & 5.450 & & \\
\cline { 2 - 8 } & Total & 2814.080 & 49 & & & \\
\hline
\end{tabular}

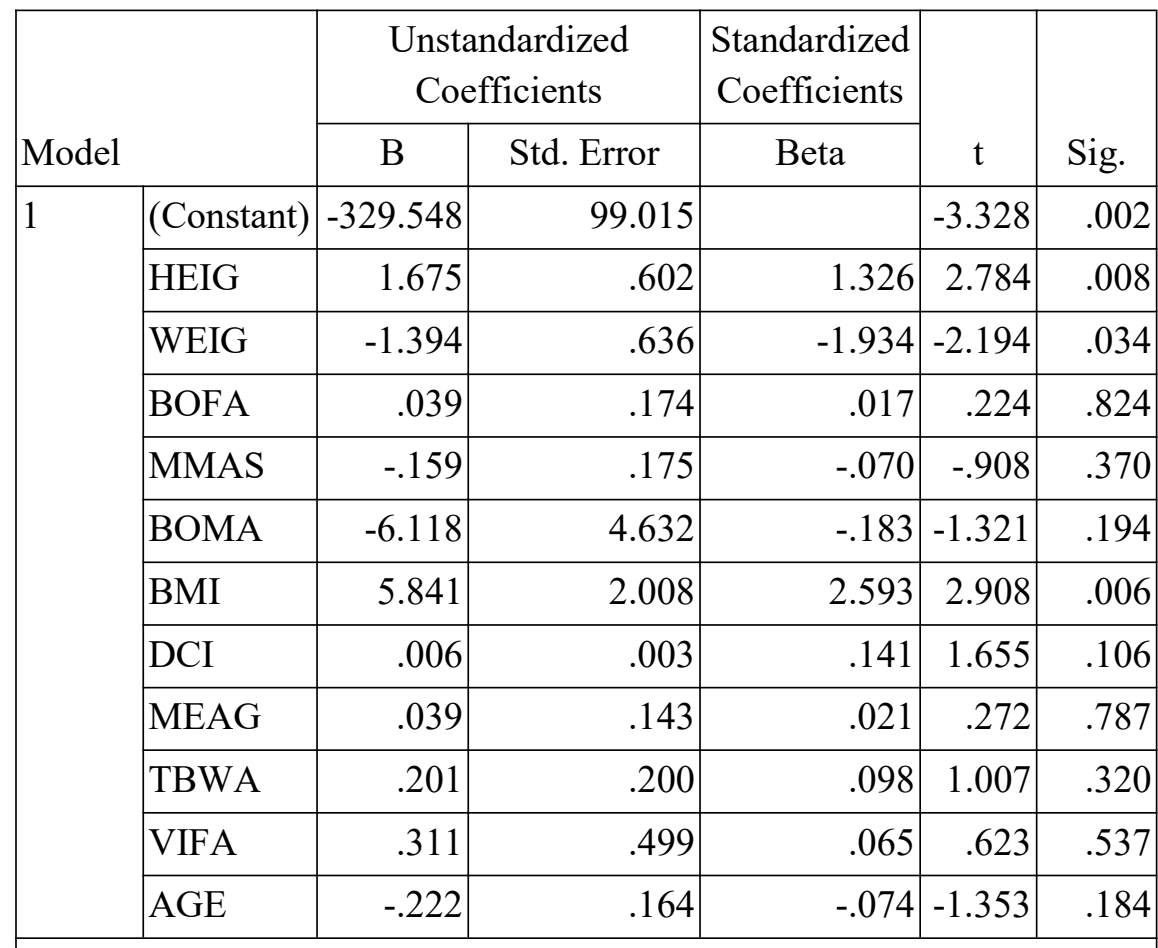

a. Dependent Variable: DEPRES

Predictive variables that influence in the manifestation of depression level are: Height of the body (HEIG) $t=2.784 ; p<0.008$, Body weight (WEIG) $t=-2.194 ; p<0.034$, and Body mass index $(\mathrm{BMI}) \mathrm{t}=2.908 ; \mathrm{p}<0.006$. Other variables of body and biochemical blood comnposition do not have significant degree of connectivity with depression level.

\section{DISCUSSION}

The intrerpretations of the results show how complex is the anthropological status of humans, especially in women. The obtained results show that no field of anthropology as they are: anthropometric characteristics, conative features, cognitive abilities, motor, functional ansocial and health status should not be considered separately during the research. From the fields of anthropology, evaluation of the morphological characteristics of body composition involves the determination of all the constituents that make up the body mass and is one of the 
most interesting areas in the science of kinesiology. Body composition is the percentage of fat, muscles and bone tissues to total body mass and are anthropometric characteristics that most women receive special treatment. Body overweight due to body characteristics is in most cases a result of the accumulation of fat under the skin that gives an unpleasant body look to women. For this reason most women try to find different ways to reduce overweight and improve the outward appearance. It can be said that being overweight causes many health problems, especially the cardiovascular system also causes psychic problems in young women 19-30 years old. This is verified in our research, which is expressed with increasing level of depression. (Mean=13.280). The depression level obtained in women in the research is slight although the maximum result indicates that in some of the women involved in the research goes up to $(\mathrm{Max}=36)$. Depression levels are: 0-9 - no depressive symptoms, 10-15 - mild depression (subdepression), 16-19 moderate depression, 20-29 - severe depression (moderate) and 30-63 - severe depression (Beck, et.al.1961). Research shows that although mental and physical health are two separate concepts, they are still in a strong relationship, physical condition often affects mental state. (Ware et al., 1981).

In women, body image shows the mental image of one's own physical appearance, assessment of look, and the influence of these perceptions and attitudes on behavior. (Pokrajac-Bulian and Kandare, 2000). Dissatisfaction with the body image of women included in the research is a component of body image, that is, of a female body image, which refers to the perceptual experience of body image and attitudes about body image. (Grabe and Hyde, 2006) maybe it has led to this slight level of depression and their desire to get involved with fitness in this age. According to some authors, body image in some young women is defined as a negative evaluation of a woman's physical appearance and is manifested with negative confidence and a negative impression of body weight and body shape. (Garner, 2002).

In Kosovo there is a society with great socio-economic differences, upper-class women pay attention to their body image, therefore, so many middle and lower class women are not happy with their body image. Current research has shown that many middle and lower class women are not satisfied with their body image and have found a connection between their lower body image evaluation and higher level of depression. (Carpenter, et al 2000). The women that were included in our research were women aged 19-30 years who have come to the fitness center for the first time. Since they have found high level of depression and have sought to get into fitness they are not happy with their body image. The worst body image is given by the overweight, specifically subcutaneous adipose tissue. Women had prior knowledge that fitness exercises to a certain extent reduce fat tissue and improve their body image. Numerous studies have also shown that a few months of exercise can affect the reduction of subcutaneous adipose tissue and body mass. (Shukova-Stojmanovska et al. 2014). With physical activity will be improved body image and indirectly will be reduced the depression level, indicating that all athletes regardless of gender have lower depression level. ( Elezi et al. 2016).

Duration of physical activity results in positive changes in a person's body image (Cash and Smolak, 2011) and prefers that when choosing physical activity, it is important to choose those physical activities that you enjoy and with great emphasis on those that have positive effects on the physical and mental aspect and emphasize that physical activity should be a strategy for changing the physical activity appearance of a person.

The high prevalence of inadequate physical activity requires the necessary development of a national strategy to improve such a situation, with a particular emphasis on the female gender of this age, as the prevalence of inadequate physical activity in these groups is the highest. 


\section{CONCLUSION}

Based on the obtained results, it can be concluded that women aged 19-30 years included in this research show a slight level of depression. The mild level of depression lies in a statistically significant relationship with body height, body weight and body mass index. This relation between depression and body image and body composition indicates a sedentary life for women included in the research, which is confirmed by the high metabolic age.

Dissatisfaction with the physical appearance of the body is a component of body image that women have not been satisfied with and as a way to improve their body image they have decided to pursue with the fitness. Awareness of the population by electronic and written means on the role of physical activity as an important health factor for individuals and the general population should be a national program. Physical activity should not only be understood as the main tool of preventing many diseases, but also as a tool of slowing down and reducing the symptoms of many chronic diseases.

\section{Reference}

1. Alić, J. (2015) Povezanost tjelesne aktivnosti studentica, samoprocjene zdravlja I zadovoljstva tjelesnim izgledom. Doktorski rad. Zagreb: Kinezioloski Fakultet, Sveučilishte u Zagrebu.

American Psychiatric Association. (2014). Diagnostic and statistical manual of mental disorders (5th ed., text rev., Vol. 14). Washington, DC: Author.

2. Anastasovski, I. (2003). Sportski način na živeenje. Kumanovo: Grafoprint. Beck, A. T., Ward C. H., Mendelson M., Mock J., Erbaugh J. (1961). An inventory for measuring depression. Archives of General Psychiatry, 4, 561-571.

3. Blumenthal J. A., Babyak M. A., Moore K. A., Craighead W. E., Herman S., Khatri P., Krishnan K. R. (1999). Effects of exercise training on older patients with major depression. Archives of Physical Medicine and Rehabilitation, 159, 2346-2349.

4. Carpenter, K. M., Hasin, D. S., Allison, D. B., \& Faith, M. S. (2000). Relationships between obesity and DSM-IV major depressive disorder, suicide ideation, and suicide attempts: Results from a general population study. American Journal of Public Health, 90, 251-257.

5. Cash, T. i Smolak, L. (2011). Understanding body images: Historical and contemporary perspectives. U T.F. Cash i L. Smolak (ur.), Body Image: A Handbook of Science, Practice, and Prevention, New York: Guilford Press, 3-11.

6. Chu, I-H. (2008). Effect of exercise intensity during aerobic training on depressive symptoms in initially sedentary depressed women. Dessertation. School of the Ohio State University.

7. Elezi, A., Rexhepi, Sh., Georgie Georgiev, G., Elezi, G., Myrtaj, N. (2016). Sports and level of depression in young sportsmen . Acta kinesiologika, 10 (2): 75-78

8. Fox, K.R. (1990). The Physical Self-Perception manual. Dekalb, IL: Northern Illinois University, Office of Health Promotion.

9. Grabe, S. i Hyde, J.S. (2006). Ethnicity and body dissatisfaction among women in the United States: a meta-analysis. Psychological Bulletin, 132(4), 622-640.

10. Lampinen P., Heikkinen R. L., Ruoppila I. (2000). Changes in intensity of physical exercise as predictors of depressive symptoms among older adults: An eight-year follow-up. Preventive Medicine, 30, 371-380.

11. Lohman, T.G. (1992). Advances in Body Composition Assessment. Champaign: Human Kinetics. 
12. Maksimović, N. i Milošević, Z. (2008). Stil života mladih Vojvodine. Novi Sad: Fakultet sporta i fizičkog vaspitanja, Savez za školski sport i olimpijsko vaspitanje.

13. Malacko, J. \& Popović, D. (1997). Metodologija kineziološko-antropoloških istraživanja (The methodology of kinesiological-anthropological researches). Priština: Fakultet fizičke culture

14. Marsh, H.W, Shavelson, R.J. (1985). Self-concept: Its multifaceted, hierarchical structure. Educational Psychologist, 20(3), 107-123.

15. Oguz, A.G., \& Oguz, O. (2017). Sports effect on depression level of elementary school students. Turkish Journal of Sport and Exercise; 19 (2), 216-221.

16. Martinsen, E.W. (1994). Physical activity and depression: Clinical experience. Acta PsychiatricaScandinavica, 377, 23-27.

17. Ostojić, S. (2005). Savremeni trendovi u analizi tjelesne strukture sportista. Sportska medicina,5(1), 1-11.

18. Overdorf, V., Kollia, B., Makarec, K., \& Alleva-Szeles, C.V. (2016). The Relationship Between Physical Activity and Depressive Symptoms in Healthy Older Women. Gerontology and Geriatr Med; 2: 1-8.

19. Pokrajac-Bulian, A. i Kandare, A. (2000.). Povezanost općeg nezadovoljstva tjelesnim izgledom i nekih aspekata samopoimanja u studentskoj populaciji. Psihologijske teme, 8, 63-77.

20. Shukova Stojmanovska D., Dimeski F.,\&Plincevic Gligoroska J. (2017): Losing weight at female recreationists with body building. Research in physical education, sport and health. Vol. 6., No 1, pages 67-7

21. Sudarov, N. \& Fratrić, F. (2010). Dijagnostika treniranosti sportista. Novi Sad: Pokrajinski zavod za sport.

22. Šabić, E. (2018). Fizičke aktivnosti u stilovima života osoba srednje životne dobi u Republici Srpskoj. Doktorska disertacija, Sremska Kamenica: Fakultet za sport i turizam.

23. Ware, J.E.Jr., Brook, R.H., Davies, A.R., Lohr, K.N. (1981). Choosing measures of health status for individuals in general populations. American Journal of Public Health, 71(6), 620-625.

24. Wolk S. I., Weissman M. M. (1995). Women and depression. In Oldham J. M., Riba M. B., editors. (Eds.), Review of psychiatry (Vol. 14, pp. 227-260). Washington, DC: American Psychiatric Press.

25. World Health Organization. (2006). Diet and physical activity: a public health priority. Preuzeto Jul 2017 iz Global Strategy on Diet, Physical Activity and Health: http://www.who.int/dietphysicalactivity/public-health-priority/en/

26. Zarshenas, S., Houshvar, P., Tahmasebi, A. (2013). The effect of short-term aerobic exercise on depression and body image in Iranian women. Depress Res Treat. 2013:132684 